\title{
Dietary calcium and phosphate restriction in guinea-pigs during pregnancy: fetal mineralization induces maternal hypocalcaemia despite increased 1 $\alpha, 25$-dihydroxycholecalciferol concentrations
}

\author{
Katrien Rummens ${ }^{1 *}$, Erik Van Herck ${ }^{2}$, Rita van Bree ${ }^{1}$, Roger Bouillon ${ }^{2}$, F. André Van Assche ${ }^{1}$ and \\ Johan Verhaeghe ${ }^{1,2}$ \\ ${ }^{1}$ Department of Obstetrics and Gynaecology, and ${ }^{2}$ Laboratorium voor Experimentele Geneeskunde en Endocrinologie, \\ Katholieke Universiteit Leuven, 3000 Leuven, Belgium
}

(Received 23 August 1999 - Revised 23 December 1999 - Accepted 28 February 2000)

\begin{abstract}
Guinea-pig fetuses at term are mineralized to a degree comparable with human fetuses, which makes the guinea-pig an attractive animal model to study maternal-fetal interactions with regard to $\mathrm{Ca}$ and phosphate $(\mathrm{P})$ homeostasis. We studied non-pregnant and pregnant (day 57) vitamin D-replete guinea-pigs, fed either a normal guinea-pig chow with $9.6 \mathrm{~g} \mathrm{Ca} / \mathrm{kg}$ and $4.9 \mathrm{~g}$ $\mathrm{P} / \mathrm{kg}$ or a study diet with $2 \mathrm{~g} \mathrm{Ca} / \mathrm{kg}$ and $1 \mathrm{~g} \mathrm{P} / \mathrm{kg}$ (low-Ca-P diet) for 7-8 weeks. Both pregnancy and the low-Ca-P diet decreased plasma concentrations of 25-hydroxycholecalciferol $\left(25(\mathrm{OH}) \mathrm{D}_{3}\right)$, but increased total and free $1 \alpha, 25$-dihydroxycholecalciferol $\left(1,25(\mathrm{OH})_{2} \mathrm{D}_{3}\right)$, strongly suggesting an additive stimulation of $1 \alpha$-hydroxylase activity. Maternal and fetal $25(\mathrm{OH}) \mathrm{D}_{3}$ and $1,25(\mathrm{OH})_{2} \mathrm{D}_{3}$ levels were highly correlated $(r 0.82$ and 0.92 respectively, $P<$ 0.001). Dual-energy absorption X-ray absorptiometry (DXA) showed that both pregnancy and the low-Ca-P diet decreased bone mineral density (BMD) of the maternal femur, particularly at the distal metaphysis. Despite higher $1,25(\mathrm{OH})_{2} \mathrm{D}_{3}$ concentrations and lower BMD, pregnant animals on the low-Ca-P diet were hypocalcaemic; blood $\mathrm{Ca}^{2+}$ levels were inversely correlated with the number of fetuses in this group $(r-0.93, P<0.001)$. Fetal growth as well as mineralization (assessed by whole-body and femoral DXA, bone histomorphometry and plasma-bone osteocalcin measurements) were unaltered in the low-Ca-P group. In conclusion, fetal mineralization proceeds normally but induces maternal hypocalcaemia in guinea-pigs with dietary restriction of $\mathrm{Ca}$ and $\mathrm{P}$.
\end{abstract}

Pregnancy: Dietary calcium restriction: Guinea-pig

The human fetus accumulates about $24 \cdot 3 \mathrm{~g} \mathrm{Ca}$, mostly during the third trimester (Iob \& Swanson, 1934). The pregnant mother provides this extra $\mathrm{Ca}$ through increased intestinal $\mathrm{Ca}$ absorption, whilst there is no skeletal demineralization (Cross et al. 1995; Ritchie et al. 1998). Intestinal $\mathrm{Ca}$ absorption includes: (1) the paracellular $\mathrm{Ca}$ transport, which is a linear function of $\mathrm{Ca}$ intake; (2) the transcellular $\mathrm{Ca}$ absorption. The latter occurs primarily in the duodenum, and is stimulated by $1 \alpha, 25$-dihydroxycholecalciferol $\left(1,25(\mathrm{OH})_{2} \mathrm{D}_{3}\right)$ at multiple sites in the absorptive cells (Bronner, 1992). Longitudinal studies in North American women have documented a $28-40 \%$ increase in $\mathrm{Ca}$ intake from the pre-pregnant state to the third trimester (Cross et al. 1995; Ritchie et al. 1998). In addition, serum concentrations of both total and free $1,25(\mathrm{OH})_{2} \mathrm{D}_{3}$ have consistently been found to be increased during late pregnancy (for review see Verhaeghe \& Bouillon, 1992). Ca supplements are not therefore advocated for pregnant women in North America (Institute of Medicine, 1998). However, it is not known to what extent the fetal $\mathrm{Ca}$ homeostasis is regulated by the maternal $\mathrm{Ca}$ intake, and whether normal fetal mineralization is ensured in women with a low $\mathrm{Ca}$ intake. $\mathrm{Ca}$ intake during pregnancy is particularly low in Africa (for example, $0.4 \mathrm{~g} / \mathrm{d}$ in The Gambia (Prentice et al. 1993)), and Ca deficiency appears to be the primary cause of rickets in African children (Oginni et al. 1996). Abnormal fetal mineralization may have long-term effects: preliminary results show that $\mathrm{Ca}$

\footnotetext{
Abbreviations: BMC, bone mineral content; BMD, bone mineral density; DBP, vitamin D-binding protein; DXA, dual-energy X-ray absorptiometry; IGF-I, insulin-like growth factor-I; $25(\mathrm{OH}) \mathrm{D}_{3}, 25$-hydroxycholecalciferol; $1,25(\mathrm{OH})_{2} \mathrm{D}_{3}, 1 \alpha, 25$-dihydroxycholecalciferol.

* Corresponding author: Dr Katrien Rummens, fax + 3216 344205, email katrien.rummens@uz.kuleuven.ac.be
} 
intake during pregnancy is one of the predictive factors of bone mineral density (BMD) measured in 8-year-old children in Tasmania (Jones et al. 1997).

The guinea-pig appears to be a suitable animal model for the study of maternal-fetal bone mineral homeostasis. Similar to the findings in human fetuses (Verhaeghe et al. 1995), plasma osteocalcin levels (a biochemical measure of bone formation) are several-fold higher in fetal than in adult female non-pregnant or pregnant guinea-pigs, with peak concentrations around day 57 (gestation length in guinea pigs is 63-68 d) (Verhaeghe et al. 1994). The whole body $\mathrm{Ca}$ content of guinea-pig fetuses at term 11.31$14.29 \mathrm{~g} / \mathrm{kg}$ fat-free mass) is slightly higher than that of human fetuses $(9.55 \mathrm{~g} / \mathrm{kg}$ ) (Widdowson, 1950; Engle \& Lemons, 1986). The maternal-fetal Ca transfer rate at the end of guinea-pig gestation demands a rapid removal of the maternal plasma $\mathrm{Ca}$ pool (Twardock, 1967) and is correlated with the placental blood-flow rate (Symonds et al. 1978). Rodent fetuses, on the other hand, have a low Ca content $(3.06 \mathrm{~g} / \mathrm{kg}$ in the rat, and $3.43 \mathrm{~g} / \mathrm{kg}$ in the mouse at the end of gestation; Widdowson, 1950). Plasma osteocalcin concentrations in fetal rats $1 \mathrm{~d}$ before birth are about $20 \%$ of levels in adult female rats, but increase rapidly after birth with peak concentrations in the late neonatal period (Verhaeghe et al. 1989, 1990).

In the present study, we examined the mineralization and plasma Ca regulation in maternal and fetal guinea-pigs on day 57 of gestation. The animals were fed either a standard guinea-pig chow with $9.6 \mathrm{~g} \mathrm{Ca}$ and $4.9 \mathrm{~g} \mathrm{P} / \mathrm{kg}$, or an experimental chow containing $2.0 \mathrm{~g} \mathrm{Ca}$ and $1.0 \mathrm{P} / \mathrm{kg}$. We preferred a restriction of both $\mathrm{Ca}$ and $\mathrm{P}$, with preservation of the $\mathrm{Ca}: \mathrm{P}$ ratio, to a Ca-deficient or a P-deficient diet.

\section{Materials and methods}

All experiments described below were approved by the Ethical Committee for animal experimentation of the K.U. Leuven, and were carried out in accordance with guidelines on the use of animals in scientific investigations.

\section{Animals}

Female guinea-pigs 2- to 3-months-old were kept for the purpose of the study in a room with a constant temperature of $22^{\circ} \mathrm{C}$ and a $12 \mathrm{~h}$ light-dark cycle. All animals received a standard guinea-pig chow, containing $9.6 \mathrm{~g} \mathrm{Ca}, 4.9 \mathrm{~g} \mathrm{P}$, $60 \mu \mathrm{g}$ cholecalciferol and $1600 \mathrm{mg}$ vitamin $\mathrm{C} / \mathrm{kg}$ (Hope Farms, Woerden, The Netherlands) ad libitum. The animals received deionized water ad libitum with added vitamin C $(400 \mathrm{mg} / \mathrm{l})$; guinea-pigs are susceptible to vitamin $\mathrm{C}$ deficiency because, like man, they lack an ascorbate synthetic pathway. Some of the animals were mated during the weekdays; the presence of a copulation plug was checked twice daily. Once a plug was detected, the animal was kept in a separate cage; this day was defined as day 1 of pregnancy. During pregnancy, the first group of animals were fed the same diet as before, whilst a second group received an experimental diet that contained $2.0 \mathrm{~g} \mathrm{Ca}$ and $1.0 \mathrm{~g} \mathrm{P} / \mathrm{kg}$ but was otherwise comparable with the standard diet (Hope Farms). The experimental diet was introduced over a $7 \mathrm{~d}$ period, in a standard-experimental diet mixture
(50:50, w/w). Non-pregnant animals on the experimental diet received the diet for the same period. All animals received fluorochrome labelling with calcein (Sigma, St Louis, MO, USA), $16 \mathrm{mg} / \mathrm{kg}$ intramuscularly, on days 49 and 56 of pregnancy or at the equivalent intervals in nonpregnant animals. On day 57 of pregnancy, the animals were transported to the laboratory, and underwent a Caesarean section (or laparotomy for non-pregnant animals) between 10.00 and 14.00 hours. Prior to surgery, the guinea-pigs were anaesthetized with ketamine hydrochloride $(48 \mathrm{mg} / \mathrm{kg})$ and xylazine hydrochloride $(6 \mathrm{mg} / \mathrm{kg})$, both intramuscularly. The abdomen was opened by a midline incision, after subcutaneous injection of xylocaine $(2 \%)$ in the incision area. In pregnant animals, the uterus was exposed from left to right. The fetuses were exposed through small uterine incisions, and a blood sample was taken from their abdominal aorta through a midline laparotomy incision, with the umbilical cord still attached to the placenta. The fetuses and their placentas were weighed. The sample from the last fetus was kept for $\mathrm{Ca}^{2+}$ and, after centrifugation, for plasma $\mathrm{P}$ measurement. The plasma samples from the previous fetuses were kept for measurement of 25-hydroxycholecalciferol $\left(25(\mathrm{OH}) \mathrm{D}_{3}\right)$, osteocalcin, $1,25(\mathrm{OH})_{2} \mathrm{D}_{3}$, vitamin D-binding protein (DBP) and insulin-like growth factor-I (IGF-I), in that order. The last (or only) fetus per litter was eviscerated and kept at $-20^{\circ} \mathrm{C}$ for dual-energy X-ray absorptiometry (DXA) measurements. From the previous fetuses, tibiae were removed for histomorphometrical evaluation, the left and right femur were kept at $-20^{\circ} \mathrm{C}$ for DXA measurements and biomechanical measurements respectively, and both humeri were kept at $-80^{\circ} \mathrm{C}$ for osteocalcin measurement. A blood sample was taken from the maternal abdominal aorta, and the guinea-pig was killed by cervical dislocation. Bones (tibiae, femora and humeri) were removed for the same purposes as indicated for the fetuses. The laparotomy, with blood and tissue sampling, did not exceed $45 \mathrm{~min}$; the animal remained anaesthetized throughout. Maternal and fetal blood $\mathrm{Ca}^{2+}$ measurement was done within $10 \mathrm{~min}$ of the maternal sample collection.

\section{Assays}

Plasma was stored at $-20^{\circ} \mathrm{C}$ until assay; all analyses, except blood $\mathrm{Ca}^{2+}$ and plasma $1,25(\mathrm{OH})_{2} \mathrm{D}_{3}$, were done in a single run. $\mathrm{Ca}^{2+}$ was measured by the ion-selective electrode method on the Ciba Corning Z88 Blood Gas System (Chiron Diagnostics, Zaventem, Belgium). Plasma $\mathrm{P}$ was measured by colorimetry with ammonium molybdate (Verhaeghe et al. 1988a). 25(OH) $\mathrm{D}_{3}$ was measured by direct competitive protein binding assay (Bouillon et al. 1984), $1,25(\mathrm{OH})_{2} \mathrm{D}_{3}$ by radioimmunoassay after HPLC purification (Bouillon et al. 1981), and DBP by a single radial immunodiffusion assay specific for guinea-pig DBP (Verhaeghe et al. 1994); the 'free $1,25(\mathrm{OH})_{2} \mathrm{D}_{3}$ index' was calculated as the $1,25(\mathrm{OH})_{2} \mathrm{D}_{3}$ :DBP molar ratio $\left(\times 10^{-5}\right)$ (Bouillon et al. 1981). Osteocalcin was measured in plasma and bone by radioimmunoassay specific for guinea-pig osteocalcin (Verhaeghe et al. 1994). The molecular mass of guinea-pig osteocalcin, derived by amino acid analysis, is $5492 \mathrm{Da}$; the amino acid composition (forty-nine residues) 
is comparable with that reported for human osteocalcin (data not shown). Osteocalcin measurements in the humeri were performed as described (Verhaeghe et al. 1989), in 10-15 mg dry bone per sample; for fetuses, both humeri were pooled to this end. IGF-I was measured by radioimmunoassay with recombinant human IGF-I as the reference standard; prior to the radioimmunoassay, the IGF-binding proteins were removed using Econo-Pac columns (Bio-Rad, Richmond, CA, USA), as described previously (Verhaeghe et al. 1997b). This purification is more effective than simple acid ethanol extraction. Indeed, the eluted fractions of both adult and fetal plasma samples contained all of the radiolabelled IGF-I. By contrast, acidethanol-extracted plasma, applied on a Superose-12 column (Pharmacia, Uppsala, Sweden) with radiolabelled IGF-I, contained a larger peak compatible with IGF-I bound to IGF-binding proteins, and a smaller peak of 'free' IGF-I (data not shown).

\section{Bone studies}

DXA analysis of adult and fetal femora and of whole fetuses was performed using a Hologic QDR-1000 absorptiometer (Hologic Inc., Waltham, MA, USA), as described previously (Verhaeghe et al. 1997a). For the adult femora, we measured the bone mineral content (BMC) and bone mineral density (BMD) of the whole femur, a mid-diaphyseal area consisting exclusively of cortical bone, and a metaphyseal area with both trabecular and cortical bone at $20 \%$ from the distal end of the femur. The femoral length and the mid-diaphyseal anteriorposterior and medial-lateral diameter were also measured.

Histomorphometrical analysis of adult tibiae was performed as described previously for rat tibiae (Verhaeghe et al. 1997a). Briefly, the undecalcified left tibia was embedded in methylmetacrylate, and longitudinal sections (4 $\mu \mathrm{m})$ were cut. Static morphometry was performed using a VIDAS 21 Image Analyzing Computer (Kontron, Munich, Germany), on von Kossa-stained sections for the measurement of trabecular bone volume (BV/TV), or on Goldner-stained sections for the measurement of osteoid surface (OS/BS) and thickness (O.Th.). Three sections were measured per animal, with $100 \mu \mathrm{m}$ in-between. Dynamic morphometry was performed by measuring the double- and single-labelled surfaces (dLS/BS and sLS/BS respectively), and the mineral apposition rate (MAR) as the mean distance (divided by labelling time interval) between all double labels measured at three equidistant intervals per label: 52 (SEM 4) labels were measured per section ( $n$ 99). The bone formation rate, surface referent (BFR/BS), was calculated as mineralizing surface $(\mathrm{MS} / \mathrm{BS}=\mathrm{dLS} / \mathrm{BS}+$ $\left.\frac{1}{2} \mathrm{sLS} / \mathrm{BS}\right) / \mathrm{MAR} \times \pi / 4$. The right tibia was decalcified, embedded in methylmetacrylate and JB-4 kit (Polysciences, Warrington, PA, USA) in a 1:3 ratio, and processed for tartrate-resistant acid phosphatase (TRAP)-staining as described previously (Verhaeghe et al. 1997a). The trabecular surface covered by TRAP-positive cells (osteoclasts and preosteoclasts), in analogy with the osteoid surface (OS/BS), was denoted as TRAPS/BS. All measurements were performed in the secondary spongiosa, starting at $1 \mathrm{~mm}$ from the distal growth plate. Trabecular bone volume (BV/TV) was measured in four consecutive fields in the vertical axis of the central metaphysis at magnification $\times 150$. The other static and dynamic measurements were performed on trabecular bone surface, excluding the endocortical and subcortical bone surface, in as many fields as possible (mean number of fields per section 30 (SEM 1); mean trabecular bone surface 29153 (SEM 1648) $\mu \mathrm{m} ; n$ 99), at magnification $\times 300$. The left fetal tibia was processed in the same way as the left maternal tibia (undecalcified, embedded in methylmetacrylate, sections $4 \mu \mathrm{m}$ thick). Dynamic morphometry could not be performed, because the labelling, although abundant, was patchy. Static morphometry included the measurement of trabecular volume (BV/TV), osteoid surface (OS/BS) and osteoid thickness (O.Th.): these measurements were done at magnification $\times 300$ in the central part of the proximal tibia, starting at $1 \mathrm{~mm}$ from the distal growth plate (average number of fields per section 13 (SEM 0.4). The histomorphometrical abbreviations are those proposed by Parfitt et al. (1987).

\section{Data analysis}

Data analysis was performed with a software program (NCSS, Kaysville, UT, USA). In adult animals, the effects of: (1) pregnancy and (2) the low-Ca-P diet were studied by two-factor ANOVA. If an interactive effect between both was detected $(P<0 \cdot 15)$ for a particular variable, we proceeded to one-way ANOVA to detect an overall difference between the four groups; if one-way ANOVA was significant $(P<0.05)$, the four individual adult groups were compared using Fisher's LSD multiple comparison test. Comparisons between groups were considered as significantly different if $P<0 \cdot 05$. Fetuses of the two diet groups and fetus-mother pairs within the same diet group were compared by unpaired and paired $t$ tests respectively, taking the variance of the data into account. All $t$ test comparisons were considered as significantly different if $P<0.05$.

\section{Results}

The low-Ca-P diet did not alter the body weight of nonpregnant, pregnant and fetal guinea-pigs, nor the number of fetuses per litter and the placental weight (Table 1). There was no significant difference in the number of live fetuses per litter (3.7 (SEM 0.4)) in the normal-Ca-P group and $3 \cdot 5$ (SEM 0.5) in the low-Ca-P group. Plasma IGF-I levels in adult guinea-pigs were not influenced by pregnancy nor by the low-Ca-P diet in both adult and fetal guinea pigs.

Blood $\mathrm{Ca}^{2+}$ concentrations were lower in pregnant animals on the low-Ca-P diet compared with the other groups (Table 2). In this group, there was a negative correlation between the maternal $\mathrm{Ca}^{2+}$ and the number of fetuses (Fig. 1). Plasma $\mathrm{P}$ levels were increased by pregnancy and by the low-Ca-P diet (Table 2). Blood $\mathrm{Ca}^{2+}$ and plasma $\mathrm{P}$ levels were higher in fetal guinea pigs than in their mothers; $\mathrm{Ca}^{2+}$ levels were lower in fetuses of mothers on the low-Ca-P diet. DBP levels decreased during pregnancy, confirming our previous data (Verhaeghe et al. 1994). Concentrations of $25(\mathrm{OH}) \mathrm{D}_{3}$ were 
Table 1. Effect of a normal- or low-Ca-P diet fed for 7-8 weeks on body and placental weight, and plasma insulin-like growth factor-I (IGF-I) concentrations in adult and fetal guinea-pigs†

(Mean values with standard errors of the mean)

\begin{tabular}{|c|c|c|c|c|c|c|c|c|c|c|c|c|}
\hline & & \multicolumn{4}{|c|}{ Normal-Ca-P diet } & \multicolumn{4}{|c|}{ Low-Ca-P diet } & & & \\
\hline & & \multicolumn{2}{|c|}{$\mathrm{NPr}(n 10)$} & \multicolumn{2}{|c|}{$\operatorname{Pr}(n 7)$} & \multicolumn{2}{|c|}{$\operatorname{NPr}(n 8)$} & \multicolumn{2}{|c|}{$\operatorname{Pr}(n 8)$} & \multicolumn{3}{|c|}{ Two-factor ANOVA (adult groups)‡ } \\
\hline & & Mean & SEM & Mean & SEM & Mean & SEM & Mean & SEM & Pregnancy & Diet & Interaction \\
\hline Body weight (g) & $\begin{array}{l}\text { Adult } \\
\text { Fetus }\end{array}$ & 776 & 24 & $\begin{array}{l}1065 \\
58 \cdot 1^{\star} \S\end{array}$ & $\begin{array}{c}55 \\
1.3\end{array}$ & 796 & 31 & $\begin{array}{l}1061 \\
58 \cdot 2^{*}\end{array}$ & $\begin{array}{l}47 \\
1.4\end{array}$ & $P<0.001$ & NS & NS \\
\hline Placental weight $(\mathrm{g})$ & & & & $4 \cdot 2 \S$ & $0 \cdot 1$ & & & 4.5 & 0.2 & & & \\
\hline Plasma IGF-I (nmol/l) & $\begin{array}{l}\text { Adult } \\
\text { Fetus }\end{array}$ & 32 & 5 & $\begin{array}{l}34 \\
7 \cdot 6^{\star}\end{array}$ & $\begin{array}{l}5 \\
0.8\end{array}$ & 26 & 2 & $\begin{array}{l}31 \\
6 \cdot 1^{*}\end{array}$ & $\begin{array}{l}4 \\
0.5\end{array}$ & NS & NS & NS \\
\hline
\end{tabular}

NPr, non-pregnant; Pr, pregnant

Mean values were significantly different between fetal-maternal pairs; ${ }^{*} P<0.05$. There were no significant differences between the two fetal groups.

† For details of composition of diets see p. 496

¥ For details of statistical procedure see p. 497

$\S$ Fetal weight and placental weight relate to $n 26$ fetuses in the normal-Ca-P diet group and $n 28$ in the low-Ca-P diet group.

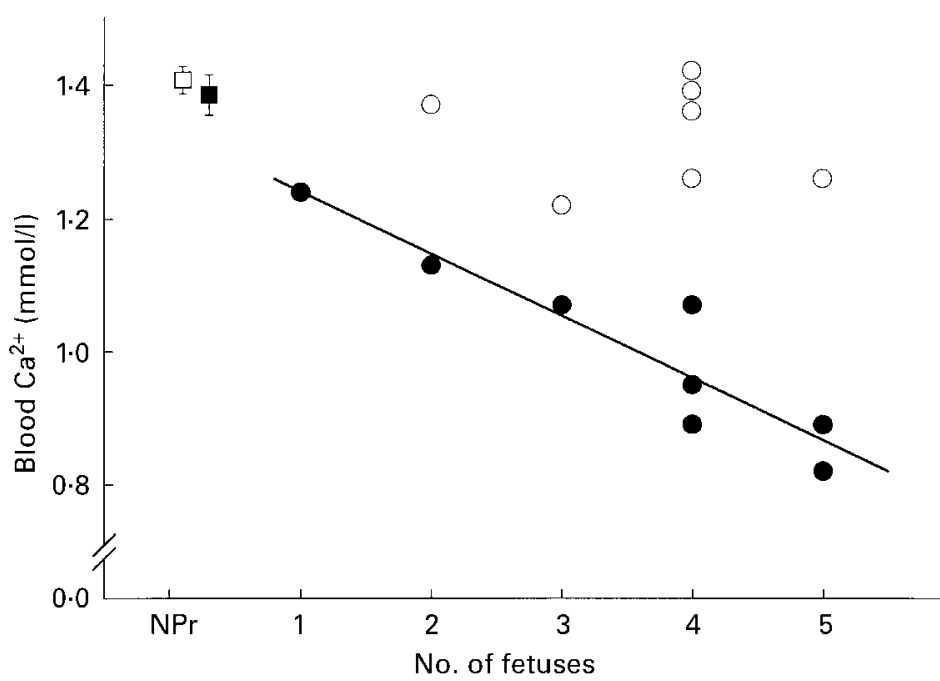

Fig. 1. Correlation between maternal blood $\mathrm{Ca}^{2+}$ and the number of fetuses in guinea-pigs fed on a normal-Ca-P diet $(O)$ or a low-Ca-P diet $(\bullet)$. For details of the diets see p. 496. There was a significant negative correlation $(r-0.93, P<0.001)$ in the low-Ca-P group, but not in the normal$\mathrm{Ca}-\mathrm{P}$ group. Mean values for the non-pregnant (NPr) groups on the normal Ca-P diet $(\square)$ and the low Ca-P diet ( $\square$ ) are also shown, with standard errors represented by vertical bars.

Table 2. Effect of a normal- or a low-Ca-P diet fed for 7-8 weeks on adult and fetal guinea-pig blood ionized calcium, plasma phosphate and plasma vitamin D-binding protein measurements $\ddagger$

(Mean values with standard errors of the mean)

\begin{tabular}{|c|c|c|c|c|c|c|c|c|c|c|c|c|c|}
\hline & & \multicolumn{4}{|c|}{ Normal-Ca-P diet } & \multicolumn{4}{|c|}{ Low-Ca-P diet } & \multirow{2}{*}{\multicolumn{3}{|c|}{$\begin{array}{l}\text { Two-factor ANOVA } \\
\text { (adult groups)§ }\end{array}$}} & \multirow{3}{*}{$\begin{array}{l}\text { One-way } \\
\text { ANOVA§ }\end{array}$} \\
\hline & & \multicolumn{2}{|c|}{$\operatorname{Npr}(n 10)$} & \multicolumn{2}{|c|}{$\operatorname{Pr}(n 7)$} & \multicolumn{2}{|c|}{$\operatorname{NPr}(n 8)$} & \multicolumn{2}{|c|}{$\operatorname{Pr}(n 8)$} & & & & \\
\hline & & Mean & SEM & Mean & SEM & Mean & SEM & Mean & $\overline{\text { SEM }}$ & Pregnancy & Diet & Interaction & \\
\hline $\mathrm{Blood} \mathrm{Ca}^{2+}(\mathrm{mmol} / \mathrm{l})$ & $\begin{array}{l}\text { Adult } \\
\text { Fetus }\end{array}$ & $1.41^{\mathrm{a}}$ & 0.02 & $\begin{array}{l}1.33^{\mathrm{a}} \\
1.46^{*} \dagger\end{array}$ & $\begin{array}{l}0.03 \\
0.03\end{array}$ & $1.39^{a}$ & 0.03 & $\begin{array}{l}1.01^{\mathrm{b}} \\
1.32^{\star} \dagger\end{array}$ & $\begin{array}{l}0.05 \\
0.03\end{array}$ & $P<0.001$ & $P<0.001$ & $P<0.001$ & $P<0.001$ \\
\hline Plasma phosphate $(\mathrm{mmol} / \mathrm{l})$ & $\begin{array}{l}\text { Adult } \\
\text { Fetus }\end{array}$ & 1.56 & 0.01 & $\begin{array}{l}1.60 \\
1.82^{\star}\end{array}$ & $\begin{array}{l}0.03 \\
0.03\end{array}$ & 1.64 & 0.02 & $\begin{array}{l}1.75 \\
1.89^{\star}\end{array}$ & $\begin{array}{l}0.04 \\
0.05\end{array}$ & $P<0.01$ & $P<0.001$ & NS & NA \\
\hline Plasma DBP $(\mu \mathrm{mol} / \mathrm{l})$ & $\begin{array}{l}\text { Adult } \\
\text { Fetus }\end{array}$ & $11 \cdot 2$ & 0.4 & $\begin{array}{l}7.9 \\
0.9^{*}\end{array}$ & $\begin{array}{l}0.5 \\
0.1\end{array}$ & $11 \cdot 3$ & $0 \cdot 6$ & $\begin{array}{l}7 \cdot 8 \\
1 \cdot 3^{*}\end{array}$ & $\begin{array}{l}0.3 \\
0.4\end{array}$ & $P<0.001$ & NS & NS & NA \\
\hline
\end{tabular}

NPr, non-pregnant; Pr, pregnant; DBP, vitamin D-binding protein; NA, not applicable.

${ }^{\mathrm{a}, \mathrm{b}}$ Mean values within a row with unlike superscript letters were signficantly different (post-hoc comparisons) $(P<0.05)$.

Mean values were significantly different between fetal-maternal pairs $\left(t\right.$ test): ${ }^{\star} P<0.05$. Mean values were significantly different between the two fetal groups (lowv. normal-Ca-P diet): $\dagger P<0.05$

$\mp$ For details of composition of diets see p. 496

$\S$ For details of the statistical procedures see p. 497. 

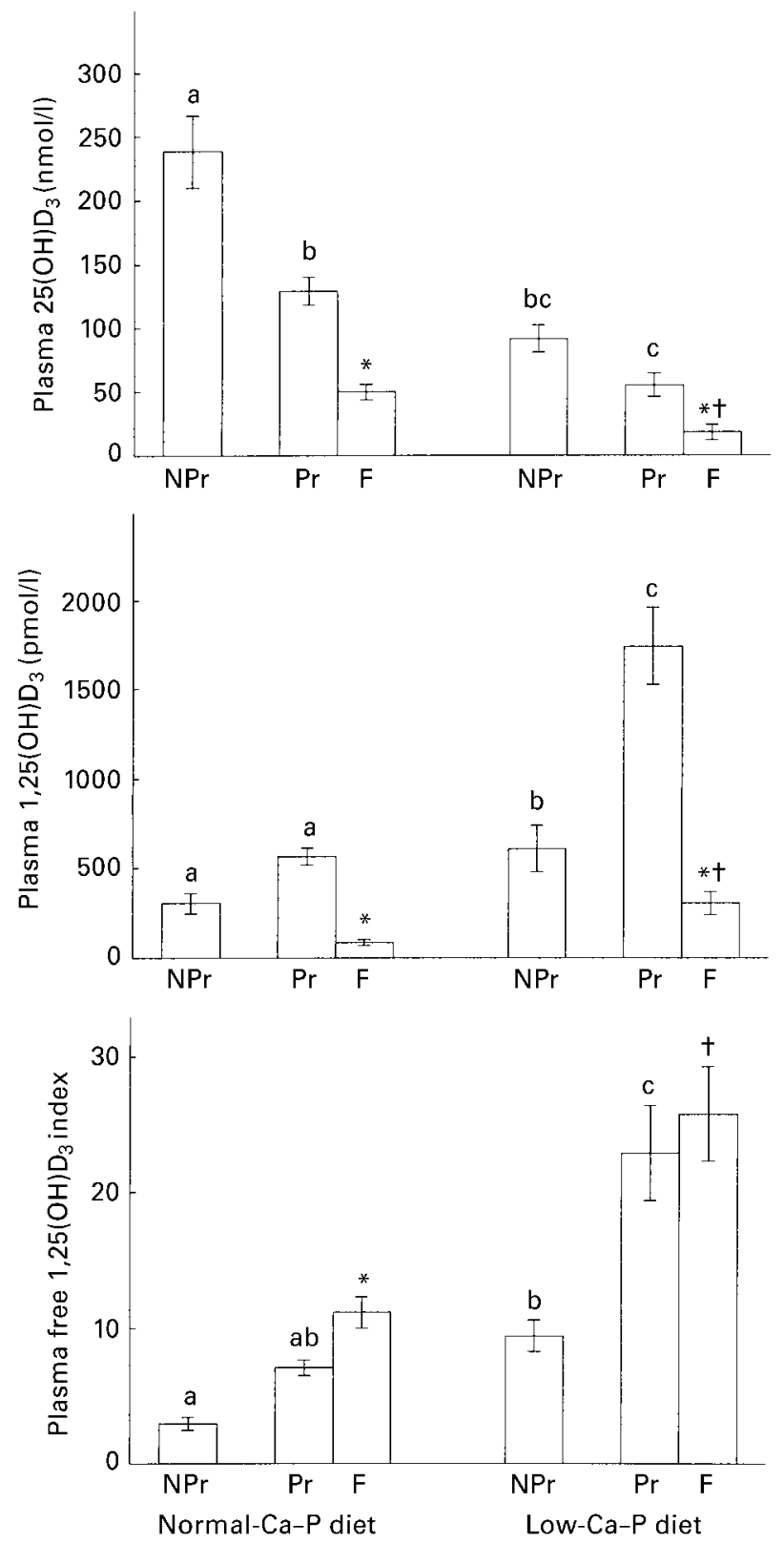

Fig. 2. Plasma concentrations of 25-hydroxycholecalciferol $\left(25(\mathrm{OH}) \mathrm{D}_{3}\right)$, and total and free 1 $1 \alpha, 25$-dihydroxycholecalciferol $\left(1,25(\mathrm{OH}) \mathrm{D}_{3}\right)$ in adult and fetal guinea-pigs, where the adult guinea-pigs were fed a normal- or low-Ca-P diet. For details of the diets see p. 496. The free $1,25(\mathrm{OH})_{2} \mathrm{D}_{3}$ index was calculated as the 1,25-dihydroxycholecalciferol:vitamin $\mathrm{D}$-binding protein molar ratio $\left(\times 10^{-5}\right)$ (Bouillon et al. 1981). NPr, non-pregnant; Pr, pregnant, $\mathrm{F}$, Fetuses. Values are means (normal-Ca-P diet; non-pregnant $n 10$, pregnant $n$ 7; low-Ca-P diet; non-pregnant $n 8$, pregnant $n$ 8) with standard errors of the means represented by vertical bars. The statistical procedure is explained on p. 497 and the ANOVA analysis for adult animals is given in Table $3 .{ }^{a, b, c}$ Mean values for adult groups with unlike superscript letters were significantly different (post-hoc comparisons) $(P<0.05)$. Mean values were significantly different from pregnant group ( $t$ test): ${ }^{\star} P<0.05$; mean values were significantly different from fetal group whose mothers received a normal-Ca-P diet $(t$ test): $† P<0.05$. decreased by pregnancy and by the low-Ca-P diet, with an additive effect in the pregnant low-Ca-P diet group (Fig. 2 and Table 3). In contrast, total and free $1,25(\mathrm{OH})_{2} \mathrm{D}_{3}$ concentrations were higher in non-pregnant and pregnant guinea-pigs on the low-Ca-P diet than in the respective animals on the normal diet; there was a further increase during pregnancy in the low-Ca-P group. Free $1,25(\mathrm{OH})_{2} \mathrm{D}_{3}$ levels tended to correlate with the number of fetuses in the low-Ca-P diet-group (Spearman correlation $r 0 \cdot 68, P=0 \cdot 07, n 8)$. Fetal guinea-pigs had lower $25(\mathrm{OH}) \mathrm{D}_{3}$ and $1,25(\mathrm{OH})_{2} \mathrm{D}_{3}$ levels than their mothers. The fetal free $1,25(\mathrm{OH})_{2} \mathrm{D}_{3}$ levels were comparable (low-Ca-P group) or higher (normal-Ca-P group) than the respective maternal levels, because of low fetal DBP levels (Table 2). The $\mathrm{Ca}^{2+}$ level was inversely correlated with $1,25(\mathrm{OH})_{2} \mathrm{D}_{3}$ concentrations in both adult and fetal guinea-pigs (Table 4); in adult guinea-pigs, $\mathrm{Ca}^{2+}$ was also inversely correlated with plasma $\mathrm{P}$ and was positively correlated with $25(\mathrm{OH}) \mathrm{D}_{3}$ levels. Maternal and fetal plasma concentrations of $25(\mathrm{OH}) \mathrm{D}_{3}$ and $1,25(\mathrm{OH})_{2} \mathrm{D}_{3}$, both total and free, were strongly correlated; maternal and fetal blood $\mathrm{Ca}^{2+}$, but not plasma P, levels were correlated as well. However, the fetal:maternal $\mathrm{Ca}^{2+}$ ratio was higher in the low- $v$. normal$\mathrm{Ca}-\mathrm{P}$ diet group (1.33 (SEM 0.07) v. 1.11 (SEM 0.02), $P=$ $0.02)$, whilst there was no difference in the fetal:maternal $P$ ratio (1.08 (SEM 0.03) v. 1.14 (SEM 0.03)).

Plasma osteocalcin levels were higher in guinea-pigs on the low-Ca-P diet than in the respective groups on the normal diet (Table 5); plasma osteocalcin was unaltered in pregnant animals in the normal-diet group, but was slightly higher in pregnant than in non-pregnant guinea-pigs on the low-Ca-P diet. The wet and dry weights of the adult and fetal humeri were not different between the two diet groups (data not shown). Osteocalcin concentrations in adult guinea-pig humeri were about half of the concentrations previously measured in adult rat femora (Verhaeghe et al. 1989); neither the total content nor the concentration per dry weight were significantly altered by pregnancy or the low-Ca-P diet. Plasma osteocalcin levels were negatively correlated with blood $\mathrm{Ca}^{2+}$ and $25(\mathrm{OH}) \mathrm{D}_{3}$, and positively correlated with plasma $\mathrm{P}$ as well as total and free $1,25(\mathrm{OH})_{2} \mathrm{D}_{3}$ (Table 4). Plasma osteocalcin levels were several-fold higher in fetal than in maternal guinea-pigs, confirming our previous data (Verhaeghe et al. 1994); osteocalcin concentrations in the fetal humerus were 45$48 \%$ of adult values. Fetal plasma osteocalcin levels were correlated with maternal osteocalcin levels, and tended to correlate negatively with fetal plasma $\mathrm{Ca}^{2+}$ and $25(\mathrm{OH}) \mathrm{D}_{3}$ (Table 4).

The length of the femur was higher in pregnant animals, but was unaffected by the low-Ca-P diet (Table 6). The medial-lateral diameter of the femoral diaphysis was slightly higher in the low-Ca-P-diet groups $(P=0.03)$, whilst pregnancy had no effect; the anterior-posterior diameter showed no significant differences by two-factor ANOVA (data not shown).

DXA measurements of the femur showed no overall differences by ANOVA for the total BMC; however, the total femoral BMD was decreased both by pregnancy and by the low-Ca-P diet (Table 6). Measurements at the distal metaphysis showed that both BMC (data not shown) and 
Table 3. Statistical analysis (ANOVA) of vitamin D metabolites in adult guinea-pigs fed a normal- or a low-Ca-P diet* (complementary to Fig. 2)

\begin{tabular}{|c|c|c|c|c|}
\hline & \multicolumn{3}{|c|}{ Two-factor ANOVA† } & \multirow[b]{2}{*}{ One-way ANOVA† } \\
\hline & Pregnancy & Low-Ca-P diet & Interaction & \\
\hline $\begin{array}{l}\text { Plasma } 25(\mathrm{OH}) \mathrm{D}_{3} \\
\text { Plasma } 1,25(\mathrm{OH})_{2} \mathrm{D}_{3} \\
\text { Plasma free } 1,25(\mathrm{OH})_{2} \mathrm{D}_{3} \text { index } \neq\end{array}$ & $\begin{array}{l}P<0.001 \\
P=0.002 \\
P<0.001\end{array}$ & $\begin{array}{l}P<0.001 \\
P<0.001 \\
P<0.001\end{array}$ & $\begin{array}{l}P=0.08 \\
P=0.12 \\
P=0.01\end{array}$ & $\begin{array}{l}P<0.001 \\
P<0.001 \\
P<0.001\end{array}$ \\
\hline
\end{tabular}

$25(\mathrm{OH}) \mathrm{D}_{3}, 25$-hydroxycholecalciferol; $1,25(\mathrm{OH})_{2} \mathrm{D}_{3}, 1 \alpha, 25$-dihydroxycholecalciferol.

${ }^{*}$ For details of composition of diets see p. 496.

† For details of statistical procedures see p. 497.

$\ddagger 1,25$-Dihydroxycholecalciferol:vitamin D-binding protein molar ratio $\left(\times 10^{-5}\right)$ (Bouillon et al. 1981).

BMD were lowered by pregnancy and the low-Ca-P diet. In addition, the mid-diaphyseal BMD was slightly lower in animals on the low-Ca-P diet.

Static and dynamic histomorphometry of the proximal tibial metaphysis showed, as expected, decreased trabecular bone volume (BV/TV) and increased osteoid surface (OS/ $\mathrm{BS}$ ) in the low-Ca-P-diet groups $v$. the normal diet (Table 7). Pregnant animals displayed a marked decrease in the osteoid surface (OS/BS), double-labelled surface (dLS/BS), mineralizing surface (MS/BS), mineral apposition rate (MAR), and the calculated bone formation rate, surface referent (BFR/BS); however, the tartrate-resistant acid phosphatase-positive cell surface (TRAPS/BS) remained normal. The drop in morphometric dynamic bone formation indices during pregnancy was more pronounced in the normal than in the low-Ca-P-diet group (the decrease in the low-Ca-P-diet group was not significant for the mineralizing surface (MS/BS) and the mineral apposition rate (MAR).

There was no significant difference in the femoral dry weight between the two fetal groups (data not shown). The total body BMC, as well as the femoral BMC, were also similar in fetuses of the normal- and low-Ca-P groups. DXA measurements revealed no differences between both groups for fetal lean and fat mass (data not shown). Trabecular bone volume (BV/TV) was also similar in both groups; osteoid bone surface (OS/BS) was slightly higher in the low-Ca-P-diet group, while osteoid thickness (O.Th.) was comparable (Table 8).

\section{Discussion}

This study demonstrates that growth and mineralization proceed normally in fetuses of guinea-pigs fed a diet restricted in $\mathrm{Ca}$ and $\mathrm{P}$ with preserved $\mathrm{Ca}: \mathrm{P}$ ratio. This confirms previous data obtained in fetuses of rats fed a similar diet (Verhaeghe et al. 1988a) or a Ca-deficient diet (Bodansky \& Duff, 1941). However, fetal rats are chemically immature at birth, whereas the mineralization of fetal guinea-pigs is far more advanced (Engle \& Lemons, 1986). In this present study, fetal mineralization was assessed by three methods: (1) BMC and BMD,

Table 4. Spearman correlation between adult $(A)$, fetal $(F)$ and maternal-fetal $(M-F)$ blood or plasma measurements in guinea-pigs fed on a normal- or a low-Ca-P diet for 7-8 weeks

(Correlation coefficients)

\begin{tabular}{|c|c|c|c|c|c|c|c|}
\hline & & $\begin{array}{l}\text { Blood ionized } \\
\text { calcium }\end{array}$ & $\begin{array}{l}\text { Plasma } \\
\text { phosphate }\end{array}$ & $\begin{array}{c}\text { Plasma } \\
25(\mathrm{OH}) \mathrm{D}_{3}\end{array}$ & $\begin{array}{c}\text { Plasma } \\
1,25(\mathrm{OH})_{2} \mathrm{D}_{3}\end{array}$ & $\begin{array}{c}\text { Free } \\
1,25(\mathrm{OH})_{2} \mathrm{D}_{3} \text { index } \S\end{array}$ & $\begin{array}{l}\text { Plasma } \\
\text { osteocalcin }\end{array}$ \\
\hline Blood ionized calcium & $\begin{array}{l}\text { Adult } \\
\text { Fetus } \\
\text { M-F }\end{array}$ & $0 \cdot 65^{\star \star} \boldsymbol{q}$ & $\begin{array}{l}-0.40^{*} \| \\
\text { NSף }\end{array}$ & $\begin{array}{l}0.63^{\star \star \star} \\
\text { NS }\end{array}$ & $\begin{array}{l}-0.56^{\star \star \star} \\
-0.56^{\star}\end{array}$ & $\begin{array}{c}-0.67^{\star \star \star} \\
\text { NS }\end{array}$ & $\begin{array}{l}-0.49^{\star \star} \\
-0.49 \dagger\end{array}$ \\
\hline Plasma phosphate & $\begin{array}{l}\text { Adult } \\
\text { Fetus } \\
\mathrm{M}-\mathrm{F}\end{array}$ & & NS & $\begin{array}{l}-0.65^{\star \star \star} \\
-0.53^{\star}\end{array}$ & $\begin{array}{l}0.79^{* * *} \\
\text { NS }\end{array}$ & $\begin{array}{l}0.78^{* * *} \\
\text { NS }\end{array}$ & $\begin{array}{l}0.78^{\star \star \star} \\
\text { NS }\end{array}$ \\
\hline Plasma $25(\mathrm{OH}) \mathrm{D}^{3}$ & $\begin{array}{l}\text { Adult } \\
\text { Fetus } \\
\text { M-F }\end{array}$ & & & $0.82^{\star \star \star}$ & $\begin{array}{l}-0 \cdot 77^{\star \star \star} \\
-0.75^{\star \star}\end{array}$ & $\begin{array}{l}-0 \cdot 82^{\star \star \star} \\
-0.81^{\star \star \star}\end{array}$ & $\begin{array}{l}-0.64^{\star \star *} \\
-0.47 \dagger\end{array}$ \\
\hline Plasma $1,25(\mathrm{OH})_{2} \mathrm{D}_{3}$ & $\begin{array}{l}\text { Adult } \\
\text { Fetus } \\
\text { M-F }\end{array}$ & & & & $0.92^{\star * *}$ & $\begin{array}{l}0.96^{\star * *} \\
0.75^{\star *}\end{array}$ & $\begin{array}{l}0.77^{\star \star \star} \\
\text { NS }\end{array}$ \\
\hline Free $1,25(\mathrm{OH})_{2} \mathrm{D}_{3}$ index $\S$ & $\begin{array}{l}\text { Adult } \\
\text { Fetus } \\
\text { M-F }\end{array}$ & & & & & $0.83^{\star \star *}$ & $\begin{array}{l}0.78^{\star \star \star} \\
N S\end{array}$ \\
\hline Plasma osteocalcin & $\begin{array}{l}\text { Adult } \\
\text { Fetus } \\
\text { M-F }\end{array}$ & & & & & & $0.57^{\star}$ \\
\hline
\end{tabular}

25(OH) $\mathrm{D}_{3}, 25$-hydroxycholecalciferol; $1,25(\mathrm{OH})_{2} \mathrm{D}_{3}, 1 \alpha, 25$-dihydroxycholecalciferol.

Correlation coefficients were statistically significant: $+0.05 \leq P \leq 0.10,{ }^{\star} P<0.05,{ }^{\star \star} P<0.01,{ }^{\star \star \star} P<0.001$.

$\ddagger$ For details of composition of diets see p. 496 .

$\S$ 1,25-dihydroxycholecaliciferol:vitamin D-binding protein molar ratio $\left(\times 10^{-5}\right)$ (Bouillon et al. 1981).

$\| n 33$.

I $n 15$. 
Table 5. Effect of a low-or normal-Ca-P diet fed for 7-8 weeks on osteocalcin measurements in adult and fetal guinea-pig plasma and humeri† (Mean values with standard errors of the means)

\begin{tabular}{|c|c|c|c|c|c|c|c|c|c|c|c|c|c|}
\hline & & \multicolumn{4}{|c|}{ Normal-Ca-P diet } & \multicolumn{4}{|c|}{ Low-Ca-P diet } & \multirow{2}{*}{\multicolumn{3}{|c|}{$\begin{array}{l}\text { Two-factor ANOVA } \\
\text { (adult groups)§ }\end{array}$}} & \multirow{3}{*}{$\begin{array}{l}\text { One-way } \\
\text { ANOVA§ }\end{array}$} \\
\hline & & \multicolumn{2}{|c|}{$\operatorname{NPr}(n 6)$} & \multicolumn{2}{|c|}{$\operatorname{Pr}(n 7)$} & \multicolumn{2}{|c|}{$\operatorname{NPr}(n 8)$} & \multicolumn{2}{|c|}{$\operatorname{Pr}(n 8)$} & & & & \\
\hline & & Mean & SEM & Mean & SEM & Mean & SEM & Mean & SEM & Pregnancy & Diet & Interaction & \\
\hline Plasma osteocalcin (nmol/l) & $\begin{array}{l}\text { Adult } \\
\text { Fetus }\end{array}$ & $5 \cdot 8^{a}$ & 0.4 & $\begin{array}{r}6 \cdot 1^{a} \\
43 \cdot 5^{*}\end{array}$ & $\begin{array}{l}0.4 \\
2.1\end{array}$ & $8 \cdot 6^{\mathrm{b}}$ & 0.8 & $\begin{array}{l}11 \cdot 1^{\mathrm{c}} \\
44.9^{*}\end{array}$ & $\begin{array}{l}1.0 \\
1.9\end{array}$ & $P=0.046$ & $P<0.001$ & $P=0.13$ & $P<0.001$ \\
\hline Humerus osteocalcin (nmol) & $\begin{array}{l}\text { Adult } \\
\text { Fetus }\end{array}$ & 79 & 5 & $\begin{array}{l}67 \\
2 \cdot 5^{*}\end{array}$ & $\begin{array}{l}4 \\
0 \cdot 1\end{array}$ & 69 & 6 & $\begin{array}{l}62 \\
2 \cdot 8^{*}\end{array}$ & $\begin{array}{l}4 \\
0 \cdot 2\end{array}$ & $P=0.07$ & NS & NS & NA \\
\hline Humerus osteocalcin (nmol/g dry wt) & $\begin{array}{l}\text { Adult } \\
\text { Fetus }\end{array}$ & 116 & 7 & $\begin{array}{c}104 \\
47^{*}\end{array}$ & $\begin{array}{l}4 \\
1\end{array}$ & 107 & 7 & $\begin{array}{l}106 \\
51^{\star}\end{array}$ & $\begin{array}{l}6 \\
2\end{array}$ & NS & NS & NS & NA \\
\hline
\end{tabular}

NPr, non-pregnant; Pr, pregnant; NA, not applicable.

a,b,c Mean values within a row with unlike superscript letters were significantly different (post-hoc comparisons) $(P<0.05)$.

Mean values were significantly different between fetal-maternal pairs $\left(t\right.$ test): ${ }^{\star} P<0.05$. Mean values between the two fetal groups were not significantly different. $\dagger$ For details of composition of diets see p. 496.

$\S$ For details of statistical procedures see p. 497.

Table 6. Effect of a normal- or low-Ca-P diet fed for 7-8 weeks on length, and dual-energy X-ray absorptiometry measurements of adult guineapig femora*

(Mean values with standard errors of the mean)

\begin{tabular}{|c|c|c|c|c|c|c|c|c|c|c|c|}
\hline & \multicolumn{4}{|c|}{ Normal-Ca-P diet } & \multicolumn{4}{|c|}{ Low-Ca-P diet } & & & \\
\hline & \multicolumn{2}{|c|}{$\operatorname{NPr}(n 10)$} & \multicolumn{2}{|c|}{$\operatorname{Pr}(n 7)$} & \multicolumn{2}{|c|}{$\operatorname{NPr}(n 8)$} & \multicolumn{2}{|c|}{$\operatorname{Pr}(n 8)$} & \multicolumn{3}{|c|}{ Two-factor ANOVA $^{\dagger}$} \\
\hline & Mean & SEM & Mean & SEM & Mean & SEM & Mean & SEM & Pregnancy & Diet & Interaction \\
\hline Length of femur (mm) & $44 \cdot 0$ & 0.5 & $45 \cdot 8$ & 0.4 & $45 \cdot 1$ & 0.5 & $46 \cdot 2$ & 0.5 & $P=0.01$ & NS & NS \\
\hline BMD of total femur $\left(\mathrm{mg} / \mathrm{cm}^{2}\right)$ & 216 & 3 & 204 & 8 & 200 & 4 & 185 & 5 & $P=0.009$ & $P=0.001$ & NS \\
\hline BMD at mid-diaphysis $\left(\mathrm{mg} / \mathrm{cm}^{2}\right)$ & 207 & 3 & 206 & 10 & 197 & 5 & 190 & 7 & NS & $P=0.049$ & NS \\
\hline BMD at distal metaphysis $\left(\mathrm{mg} / \mathrm{cm}^{2}\right)$ & 186 & 6 & 165 & 6 & 157 & 3 & 142 & 4 & $P=0.001$ & $P<0.001$ & NS \\
\hline
\end{tabular}

NPr, non-pregnant; Pr, pregnant; BMD, bone mineral density.

* For details of composition of diets see p. 496.

$\dagger$ For details of statistical procedures see p. 497.

Table 7. Effect of a normal- or low-Ca-P diet fed for 7-8 weeks on static and dynamic histomorphometry of the proximal tibial metaphysis in adult guinea-pigs

(Mean values with standard errors of the mean)

\begin{tabular}{|c|c|c|c|c|c|c|c|c|c|c|c|c|}
\hline & \multicolumn{4}{|c|}{ Normal-Ca-P diet } & \multicolumn{4}{|c|}{ Low-Ca-P diet } & \multirow{2}{*}{\multicolumn{3}{|c|}{ Two-factor ANOVA $\ddagger$}} & \multirow[b]{3}{*}{ One-way ANOVA $\ddagger$} \\
\hline & \multicolumn{2}{|c|}{$\operatorname{NPr}(n 10)$} & \multicolumn{2}{|c|}{$\operatorname{Pr}(n 7)$} & \multicolumn{2}{|c|}{$\operatorname{NPr}(n 8)$} & \multicolumn{2}{|c|}{$\operatorname{Pr}(n 8)$} & & & & \\
\hline & Mean & $\overline{\text { SEM }}$ & Mean & $\overline{\text { SEM }}$ & Mean & $\overline{\text { SEM }}$ & Mean & $\overline{\text { SEM }}$ & Pregnancy & Diet & Interaction & \\
\hline \multicolumn{13}{|l|}{ Static morphometry: } \\
\hline $\mathrm{BV} / \mathrm{TV}(\%)$ & $3 \cdot 3$ & 1.0 & 1.9 & 0.5 & 0.4 & 0.1 & 0.3 & 0.1 & NS & $P=0.001$ & NS & NA \\
\hline OS/BS (\%) & 24 & 2 & 10 & 1 & 32 & 3 & 24 & 4 & $P=0.001$ & $P<0.001$ & $\mathrm{~N}$ & NA \\
\hline O.Th. $(\mu \mathrm{m})$ & 3.1 & 0.2 & $2 \cdot 8$ & 0.1 & 3.4 & 0.2 & 2.8 & 0.1 & $P=0.01$ & NS & NS & NA \\
\hline TRAPS/BS (\%) & 13 & 2 & 10 & 1 & 14 & 2 & ND & & NA & NA & NA & NS \\
\hline \multicolumn{13}{|l|}{ Dynamic morphometry: } \\
\hline $\mathrm{dLs} / \mathrm{BS}(\%)$ & $11 \cdot 3^{\mathrm{ac}}$ & 0.8 & $1.7^{b}$ & 0.4 & $13 \cdot 5^{\mathrm{a}}$ & 1.3 & $9.9^{c}$ & 1.8 & $P<0.001$ & $P<0.001$ & $P=0.02$ & $P<0.001$ \\
\hline MS/BS (\%) & $26^{a}$ & 1 & $11^{\mathrm{b}}$ & 1 & $28^{\mathrm{a}}$ & 2 & $25^{\mathrm{a}}$ & 2 & $P<0.001$ & $P<0.001$ & $P<0.001$ & $P<0.001$ \\
\hline $\operatorname{MAR}(\mu \mathrm{m} / \mathrm{d})$ & $2 \cdot 8^{\mathrm{a}}$ & 0.1 & $1.9^{\mathrm{b}}$ & 0.1 & $2 \cdot 7^{\mathrm{a}}$ & 0.1 & $2 \cdot 8^{\mathrm{a}}$ & 0.1 & $P=0.007$ & $P=0.001$ & $P<0.001$ & $P<0.001$ \\
\hline BFR/BS $\left(\mu \mathrm{m}^{2} / \mu \mathrm{m} / \mathrm{d} \times 10^{-2}\right)$ & $7 \cdot 4^{\mathrm{ac}}$ & 0.3 & $4 \cdot 4^{b}$ & 0.4 & $8 \cdot 2^{\mathrm{a}}$ & 0.4 & $7 \cdot 0^{\mathrm{C}}$ & 0.4 & $P<0.001$ & $P<0.001$ & $P=0.03$ & $P<0.001$ \\
\hline
\end{tabular}

NPr, non-pregnant; Pr, pregnant; BV/TV, trabecular bone volume; OS/BS, osteoid surface; O.Th., osteoid thickness; TRAPS/BS, tartrate-resistant acid phosphatasepositive surface; dLS/BS, double-labelled surface; MS/BS, mineralizing surface; MAR, mineral apposition rate; BFR/BS, bone formation rate, surface referent; ND, not done; NA, not applicable.

a,b,c Mean values within a row with unlike superscript letters were significantly different (post-hoc comparisons) $(P<0.05)$.

† For details of composition of diets see p. 496.

‡ For details of statistical procedures see p. 497.

measured by DXA, of a whole fetus per litter and of the femora of the other fetuses; (2) measurement of osteocalcin, the most abundant non-collagenous protein of bone (bound to hydroxyapatite) in humeri; (3) measurement of trabecular bone volume in the proximal tibia. Bone formation was assessed morphometrically by measurement of the osteoid surface and thickness, and biochemically by measurement of plasma osteocalcin. In fetuses of guineapigs fed the low-Ca-P diet, there was a slight increase in the osteoid surface, but not thickness, compared with 
Table 8. Effect of a normal- or low-Ca-P diet fed for 7-8 weeks on fetal mineralization, assessed by dual-energy X-ray absorptiometry and static histomorphometry in guinea-pigs $†$

(Mean values with standard errors of the mean)

\begin{tabular}{|c|c|c|c|c|c|c|}
\hline & \multicolumn{3}{|c|}{ Normal-Ca-P diet } & \multicolumn{3}{|c|}{ Low-Ca-P diet } \\
\hline & Mean & SEM & $n$ & Mean & SEM & $n$ \\
\hline \multicolumn{7}{|l|}{ DXA: } \\
\hline Total body BMC (g) & 1.56 & 0.05 & 7 & 1.54 & 0.05 & 8 \\
\hline Femoral BMC (mg) & $18 \cdot 3$ & 0.8 & 19 & $17 \cdot 3$ & 0.7 & 20 \\
\hline \multicolumn{7}{|l|}{ Histomorphometry: } \\
\hline BV/TV (\%) & $13 \cdot 7$ & 0.8 & 19 & 11.5 & 0.8 & 20 \\
\hline OS/BS (\%) & $13 \cdot 2$ & 0.9 & 19 & $16 \cdot 5^{\star}$ & 0.8 & 20 \\
\hline O.Th. $(\mu \mathrm{m})$ & $3 \cdot 1$ & 0.1 & 19 & 3.0 & 0.1 & 20 \\
\hline
\end{tabular}

DXA, dual-energy X-ray absorptiometry; BMC, bone mineral content; BV/TV, trabecular bone volume; OS/BS, osteoid surface; O.Th., osteoid thickness.

Mean value was significantly different from normal-Ca-P diet group ( $t$ test): ${ }^{*} P<0.05$.

† For details of composition of diets see p. 496.

control fetuses; plasma osteocalcin levels were normal, however. It needs to be determined whether the increase in osteoid surface is related to the altered endocrine environment (e.g. increased $1,25(\mathrm{OH})_{2} \mathrm{D}_{3}$ levels) of these fetuses.

Maternal guinea-pigs on the low-Ca-P diet, on the other hand, were hypocalcaemic on day 57 of gestation, whereas non-pregnant females fed this diet for a similar interval remained normocalcaemic. In addition, Fig. 1 shows that their hypocalcaemia was strongly correlated with the number of fetuses. Hence, the pregnancy-induced alterations in $1,25(\mathrm{OH})_{2} \mathrm{D}_{3}$ levels (duodenal $\mathrm{Ca}$ absorption) and skeletal mineralization (bone resorption) were insufficient to maintain normocalcaemia. By contrast, we found no hypocalcaemia in late-gravid rats fed a similar diet, irrespective of their litter size (Verhaeghe et al. 1988a). In a series of twenty-three pregnant (day 61) guinea-pigs with 1-8 fetuses per litter, fed a diet providing $11 \mathrm{~g} \mathrm{Ca}$ and $7 \mathrm{~g} \mathrm{P} / \mathrm{kg}$, there was a significant trend for maternal plasma total Ca levels to drop with increasing litter size (Symonds et al. 1978). It would be interesting to study whether women with a low $\mathrm{Ca}$ intake, for example, rural African women (Prentice et al. 1993) carrying twins, are at risk of developing hypocalcaemia at the end of pregnancy. Interestingly, in rural Yoruba-Nigerian women, one in nineteen pregnancies is a twin pregnancy (Knox \& Morley, 1960)

Fig. 2 shows that the low-Ca-P diet and pregnancy had additive effects on plasma concentrations of $25(\mathrm{OH}) \mathrm{D}_{3}$ and $1,25(\mathrm{OH})_{2} \mathrm{D}_{3}$. The effects of a Ca-deficient diet on plasma levels and on the in vivo metabolism of $25(\mathrm{OH}) \mathrm{D}_{3}$ and $1,25(\mathrm{OH})_{2} \mathrm{D}_{3}$ have been well documented in non-pregnant rats. $25(\mathrm{OH}) \mathrm{D}_{3}$ levels are decreased, due to both lower production (i.e. hepatic 25-hydroxylase activity) and higher clearance rate (i.e. renal $1 \alpha$-hydroxlase activity). The boost in $1 \alpha$-hydroxylase activity results in increased plasma $1,25(\mathrm{OH})_{2} \mathrm{D}_{3}$ levels; in addition, there is a smaller increment in the metabolic clearance rate of $1,25(\mathrm{OH})_{2} \mathrm{D}_{3}$ in Ca-deficient rats (Fox et al. 1990; Bolt et al. 1992). During pregnancy, guinea-pigs on the normal-Ca-P diet had slightly, but not significantly, higher total and free $1,25(\mathrm{OH})_{2} \mathrm{D}_{3}$ concentrations. We previously found that the rise in $1,25(\mathrm{OH})_{2} \mathrm{D}_{3}$ levels during pregnancy in guinea-pigs is confined to the very end of pregnancy (day 63), confirming similar data for rat pregnancy (Verhaeghe et al. 1994). Again, lower $25(\mathrm{OH}) \mathrm{D}_{3}$ but higher $1,25(\mathrm{OH})_{2} \mathrm{D}_{3}$ are caused by stimulation of the $1 \alpha$-hydroxylase activity, whereas there is no alteration in the metabolic clearance rate of $1,25(\mathrm{OH})_{2} \mathrm{D}_{3}$ during pregnancy (Paulson et al. 1990). Guinea-pigs on the low-Ca-P diet showed a further increase of $1,25(\mathrm{OH})_{2} \mathrm{D}_{3}$ levels on day 57 of pregnancy compared with non-pregnant guinea-pigs, and there was a trend for a significant correlation between the maternal free $1,25(\mathrm{OH})_{2} \mathrm{D}_{3}$ level and the number of fetuses. Hence, when $\mathrm{Ca}-\mathrm{P}$ intake is restricted, the $\mathrm{Ca}$ requirement for fetal mineralization results in a more robust and littersize-dependent stimulation of the maternal $1 \alpha$-hydroxylase activity. The increase in plasma $\mathrm{P}$ levels induced by pregnancy and/or the low-Ca-P diet may be related to higher circulating $1,25(\mathrm{OH})_{2} \mathrm{D}_{3}$ which stimulates intestinal $\mathrm{P}$ absorption (Walling, 1977).

This present study confirms previous data obtained in human subjects (Bouillon et al. 1981) and in several animal species (Verhaeghe et al. 1988b) that maternal and fetal plasma concentrations of $25(\mathrm{OH}) \mathrm{D}_{3}$ and $1,25(\mathrm{OH})_{2} \mathrm{D}_{3}$ are correlated with one another. Both vitamin $\mathrm{D}$ metabolites have been shown to cross the human placental barrier (Ron et al. 1984); guinea-pigs, like man, have a haemomonochorial placental membrane. It cannot be excluded, however, that guinea-pig fetuses in the low-Ca-P group produced more $1,25(\mathrm{OH})_{2} \mathrm{D}_{3}$ in response to the drop in $\mathrm{Ca}^{2+}$ levels (or a rise in parathyroid hormone levels). Indeed, the renal $1 \alpha$-hydroxylase activity of term guineapig fetuses was found to be comparable with that of their pregnant mothers and many times higher than in adult male guinea-pigs (Fenton \& Britton, 1980).

This study produces histomorphometrical evidence that bone formation is decreased during pregnancy in guineapigs: the osteoid surface, and the dynamic variables of bone formation (mineralizing surface, and mineral apposition rate) were all dampened. This would indicate that osteoblast recruitment is suppressed during pregnancy in this species. However, plasma osteocalcin levels did not decrease during pregnancy, which is at variance with our findings in a previous study in guinea-pigs (Verhaeghe et al. 1994); this issue must be investigated further. On the other hand, there was no effect on the tartrate-resistant acid phosphatase positive surface (occupied by osteoclasts or its precursors), a measure of bone resorption. We also found that the femoral BMD was lower in pregnant guinea-pigs, particularly at the distal metaphysis which is rich in trabecular bone. The effect of pregnancy on bone cell activity in other experimental mammals is controversial. In late-pregnant or day 1-postpartum rats, histomorphometrical variables of bone resorption and formation were found to be either increased or unchanged (Marie et al. 1986; Verhaeghe et al. 1988a; Tojo et al. 1998); plasma osteocalcin levels were raised in late pregnancy (Verhaeghe et al. 1989). In primates, there was either no effect or a decrease in plasma osteocalcin levels, histomorphometrical bone formation variables and bone volume during pregnancy (Lees \& Jerome, 1998; Ott et al. 1999). It is unlikely that the drop in bone formation rate during guinea-pig pregnancy is caused by oestrogen-excess, because no effect 
of ovariectomy on bone remodelling in this animal model has been found (Vanderschueren et al. 1992). Another possibility would be a decrease in IGF-I levels. Indeed, whole embryo- or fetal paw-transplants grow less rapidly in late-pregnant than in non-pregnant rat hosts, and this has been attributed to the drop in IGF-I levels during rat pregnancy (Chiang et al. 1990). However, we found no decrease in IGF-I levels during guinea-pig pregnancy.

This present study has limitations. First, we have no longitudinal data on the $\mathrm{Ca}$ intake of the guinea-pigs during pregnancy. We have performed preliminary $\mathrm{Ca}$ balance experiments in pregnant guinea-pigs (data not shown), but they were stopped because most animals refrained from eating whilst in the metabolic cage. Second, we have no longitudinal data of histomorphometrical or biochemical variables of bone formation and resorption, both after introduction of the low-Ca-P diet and during pregnancy. This will be done in further experiments to examine whether the decrease in metaphyseal bone density in pregnant guinea-pigs is caused by a sustained decrease in bone formation and/or by an increase in bone resorption at an earlier stage of pregnancy. Despite these limitations, this study demonstrates that the guinea-pig model has great potential for further research on maternal-fetal interactions in the homeostasis of $\mathrm{Ca}, \mathrm{P}$ and vitamin $\mathrm{D}$.

In conclusion, guinea-pigs with dietary restriction of $\mathrm{Ca}$ and $\mathrm{P}$ become hypocalcaemic in late pregnancy, despite increased $1,25(\mathrm{OH})_{2} \mathrm{D}_{3}$ concentrations. Fetal mineralization, however, proceeds undisturbed. Since the maternal $\mathrm{Ca}^{2+}$ level is inversely correlated with the number of fetuses, it is inferred that fetal mineralization induces maternal hypocalcaemia.

\section{Acknowledgements}

K. Rummens is supported by a grant ('Aspirant Navorser') from the Fonds voor Wetenschappelijk Onderzoek-Vlaanderen (Belgium). We thank H. Borghs, I. Jans, R. Janssens, K. Moermans and L. Vercruysse for their advice and help with the analyses; we also thank Dr K. Meurrens and M. Op De Beeck for their advice on the experimental design and care of the animals.

\section{References}

Bodansky M \& Duff VB (1941) Dependence of fetal growth and storage of calcium and phosphorus on the parathyroid function and diet of pregnant rats. Journal of Nutrition 22, 25-41.

Bolt MJG, Jensen WE \& Sitrin MD (1992) Metabolism of 25hydroxyvitamin $\mathrm{D}_{3}$ in rats: low-calcium diet vs. calcitriol infusion. American Journal of Physiology 262, E359-E367.

Bouillon R, Van Assche FA, Van Baelen H, Heyns W \& De Moor $P$ (1981) Influence of the vitamin D-binding protein on the serum concentration of 1,25-dihydroxyvitamin $\mathrm{D}_{3}$. Significance of the free 1,25-dihydroxyvitamin $\mathrm{D}_{3}$ concentration. Journal of Clinical Investigation 67, 589-596.

Bouillon R, Van Herck E, Jans I, Tan BK, Van Baelen H \& De Moor P (1984) Two direct (nonchromatographic) assays for 25hydroxyvitamin D. Clinical Chemistry 30, 1731-1736.

Bronner F (1992) Current concepts of calcium absorption: an overview. Journal of Nutrition 122, 641-643.

Chiang M, Russell SM \& Nicoll CS (1990) Growth-promoting properties of the internal milieu of pregnant and lactating rats. American Journal of Physiology 258, E98-E102.

Cross NA, Hillman LS, Allen SH, Krause GF \& Vieira NE (1995) Calcium homeostasis and bone metabolism during pregnancy, lactation, and postweaning: a longitudinal study. American Journal of Clinical Nutrition 61, 514-523.

Engle WA \& Lemons JA (1986) Composition of the fetal and maternal guinea pig throughout gestation. Pediatric Research 20, 1156-1160.

Fenton E \& Britton HG (1980) 25-Hydroxycholecalciferol $1 \alpha-$ hydroxylase activity in the kidney of the fetal, neonatal and adult guinea pig. Biology of the Neonate 37, 254-256.

Fox J, Bunker JE, Kamimura M \& Wong PF (1990) Low-calcium diets increase both production and clearance of 1,25-dihydroxyvitamin $\mathrm{D}_{3}$ in rats. American Journal of Physiology 258, E282E287.

Institute of Medicine (1998) Dietary Reference Intakes. Calcium, Phosphorus, Magnesium, Vitamin D, and Fluoride. Washington, DC: National Academy Press.

Iob V \& Swanson WW (1934) Mineral growth of the human fetus. American Journal of Diseases in Childhood 47, 302-306.

Jones G, Couper D, Riley M, Goff C \& Dwyer T (1997) Determinants of bone mass in prepubertal children: antenatal, neonatal and current influences. Journal of Bone and Mineral Research 12, Suppl. 1, S145.

Knox G \& Morley D (1960) Twinning in Yoruba women. Journal of Obstetrics and Gynaecology of the British Empire 67, 981984.

Lees CJ \& Jerome CP (1998) Effects of pregnancy and lactation on bone in cynomolgus macaques: histomorphometric analysis of iliac biopsies. Bone 22, 545-549.

Marie PJ, Cancela L, Le Boulch N \& Miravet L (1986) Bone changes due to pregnancy and lactation: influence of vitamin D status. American Journal of Physiology 251, E400-E406.

Oginni LM, Worsfold M, Oyelami OA, Sharp CA, Powell DE \& Davie MWJ (1996) Etiology of rickets in Nigerian children. Journal of Pediatrics 128, 692-694.

Ott SM, Lipkin EW \& Newell-Morris L (1999) Bone physiology during pregnancy and lactation in young macaques. Journal of Bone and Mineral Research 14, 1779-1788.

Parfitt AM, Drezner MK, Glorieux FH, Kanis JA, Malluche H, Meunier PJ, Ott SM \& Recker RR (1987) Bone histomorphometry: standardization of nomenclature, symbols and units. Journal of Bone and Mineral Research 6, 595-610.

Paulson SK, Ford KK \& Langman CB (1990) Pregnancy does not alter the metabolic clearance of 1,25-dihydroxyvitamin D in rats. American Journal of Physiology 258, E158-E162.

Prentice A, Laskey MA, Shaw J, Hudson GJ, Day KC, Jarjou LMA, Dibba B \& Paul AA (1993) The calcium and phosphorus intakes of rural Gambian women during pregnancy and lactation. British Journal of Nutrition 69, 885-896.

Ritchie LD, Fung EB, Halloran BP, Turnlund JR, Van Loan MD, Cann CE \& King JC (1998) A longitudinal study of calcium homeostasis during human pregnancy and lactation and after resumption of menses. American Journal of Clinical Nutrition 67, 693-701.

Ron M, Levitz M, Chuba J \& Dancis J (1984) Transfer of 25hydroxyvitamin $\mathrm{D}_{3}$ and 1,25-dihydroxyvitamin $\mathrm{D}_{3}$ across the perfused human placenta. American Journal of Obstetrics and Gynecology 148, 370-374.

Symonds HW, Bubar RH, Crackel W \& Twardock AR (1978) The effect of litter size on placental blood flow and placental calcium transfer in the multifoetate guinea-pig. British Journal of Nutrition 39, 347-356.

Tojo Y, Kurabayashi T, Honda A, Yamamoto Y, Yahata T, Takakuwa K \& Tanaka K (1998) Bone structural and metabolic 
changes at the end of pregnancy and lactation in rats. American Journal of Obstetrics and Gynecology 178, 180-185.

Twardock AR (1967) Placental transfer of calcium and strontium in the guinea pig. American Journal of Physiology 213, 837-842.

Vanderschueren D, Van Herck E, Suiker AMH, Allewaert K, Visser WJ, Geusens P \& Bouillon R (1992) Bone and mineral metabolism in the adult guinea pig: long-term effects of estrogen and androgen deficiency. Journal of Bone and Mineral Research 7, 1407-1415.

Verhaeghe J, Allewaert K, Van Herck E, Van Bree R, Van Assche FA \& Bouillon R (1994) 1,25-Dihydroxyvitamin $\mathrm{D}_{3}$ and osteocalcin in maternal and fetal guinea pigs. Bone and Mineral 26, 261-273.

Verhaeghe J \& Bouillon R (1992) Calciotropic hormones during reproduction. Journal of Steroid Biochemistry and Molecular Biology 41, 469-477.

Verhaeghe J, Bouillon R, Lissens W, Visser WJ \& Van Assche FA (1988a) Diabetic and low Ca-P diets have opposite effects on adult and fetal bone and mineral metabolism. American Journal of Physiology 254, E496-E504.

Verhaeghe J, Oloumi G, Van Herck E, van Bree R, Dequeker J, Einhorn TA \& Bouillon R (1997a) Effects of long-term diabetes and/or high-dose $17 \beta$-estradiol on bone formation, bone mineral density, and strength in ovariectomized rats. Bone 20, 421-428.
Verhaeghe J, Thomasset M, Bréhier A, Van Assche FA \& Bouillon $\mathrm{R}(1988 b) 1,25(\mathrm{OH})_{2} \mathrm{D}_{3}$ and Ca-binding protein in fetal rats: relationship to the maternal vitamin $\mathrm{D}$ status. American Journal of Physiology 254, E505-E512.

Verhaeghe J, Thomasset M, Van Assche FA \& Bouillon R (1990) Osteocalcin is vitamin D-dependent during the perinatal period in the rat. Journal of Developmental Physiology 14, 311-317.

Verhaeghe J, Van Herck E \& Bouillon R (1995) Umbilical cord osteocalcin in normal pregnancies and pregnancies complicated by fetal growth retardation or diabetes mellitus. Biology of the Neonate 68, 377-383.

Verhaeghe J, Van Herck E, van Bree R, Moermans K \& Bouillon R (1997b) Decreased osteoblast activity in spontaneously diabetic rats. In vivo studies on the pathogenesis. Endocrine 7, 165-175.

Verhaeghe J, Van Herck E, Van Bree R, Van Assche FA \& Bouillon R (1989) Osteocalcin during the reproductive cycle in normal and diabetic rats. Journal of Endocrinology 120, 143 151.

Walling MW, (1977) Intestinal Ca and phosphate transport: differential responses to vitamin $\mathrm{D}_{3}$ metabolites. American Journal of Physiology 233, E488-E494.

Widdowson EM, (1950) Chemical composition of newly born mammals. Nature 166, 626-628. 